[Agr. Biol. Chem., Vol. 32, No. 4, p. 514 517, 1968]

\title{
Pentose Metabolism in Candida utilis
}

\section{Part IV. NADP Specific Polyol Dehydrogenase*}

\author{
By Hiroyuki Horitsu, Mikio Tomoeda and Katsushi KumagaI \\ Department of Agricultural Chemistry, Gifu University, Gifu \\ Received May 31, 1967
}

In the previous papers, ${ }^{1,21}$ the presence of xylose-ketol isomerase and NAD specific polyol dehydrogenase for xylose metabolic system in Candida utilis was reported. But, in these papers, there has not yet been reported on metabolic system from xylose to xylitol.

Recently, the presence of NADP specific polyol dehydrogenase has been reported in Candida albicans, ${ }^{31}$ Oospora lactis ${ }^{41}$ and Candida utilis. ${ }^{51}$

In this paper were described some properties of NADP specific polyol dehydrogenase in Candida utilis which was grown in a medium containing xylose.

\section{EXPERIMENTAL AND RESULTS}

Strain and culture medium. Candida utilis No. 8 acclimated on xylose medium was used throughout these experiments. The same conditions and medium as described in the previous report were used.

Assay. NADP specific polyol dehydrogenase activity was measured by following the rate

* This paper was presented at the Central District Branch Meeting of the Agricultural Chemical Society of Japan, Gifu, October 11, 1966.

1) M. Tomoeda and H. Horitsu, Agr. Biol. Chem., 28, 139 (1964).

2) H. Horitsu and M. Tomoeda, ibid., 30, 962 (1966).

3) L. A. Veiga, M. Bacila and B. L. Horecker, Biochim. Biophys. Res. Comm., 2, 440 (1960).

4) V. Moret and S. Sperti, Arch. Biochim. Biophys., $\mathbf{9 8}, 124(1962)$.

5) B. M. Scher and B. L. Horecker, ibid., 116 , 117 (1966). of oxidation of $\mathrm{NADPH}_{2}$. The incubation mixture contained $0.2 \mathrm{M}$ tris- $\mathrm{HCl}, \mathrm{pH} 7.0$, $8.7 \times 10^{-4} \mathrm{M} \quad \mathrm{NADPH}_{2} \quad 0.067 \mathrm{M}$ D-xylose and diluted enzyme. The reaction was started by addition of $\mathrm{NADPH}_{2}$ and followed for up to $3 \mathrm{~min}$ by measuring the change of optical density at $340 \mathrm{~m} \mu$.

A unit of the enzyme was difined as the quantity required to produce a change in optical density of 0.01 per minute at $340 \mathrm{~m} \mu$.

Specific activity was expressed as units per mg protein. Protein was determined with Folin-Ciocalteu reagent. ${ }^{61}$

Unless otherwise stated, enzyme activity was measured with DEAE-fraction as the enzyme source and $\mathrm{D}$-xylose as substrate.

Purification procedure. The cells were grown as previously described and the cells thus obtained were collected at $2 \sim 5^{\circ} \mathrm{C}$ by centrifugation. The cells $(750 \mathrm{~g}$, wet weight) were washed with distilled water to be free from remaining medium and were treated by butyl acetate $(75 \mathrm{ml})$ at $37^{\circ} \mathrm{C}$ for $10 \mathrm{~min}$. After treatment, the cell-free extract was obtained by centrifugation ("crude extract" $430 \mathrm{ml}$ ).

To the crude extract $(430 \mathrm{ml})$ was added ammonium sulfate $(98 \mathrm{~g})$ to make $30 \%$ saturation. After removal the precipitate by centrifugation, the supernatant solution 430

6) S. P. Colowick and N. O. Kaplan, "Methods in Enzymology" Vol. III ed. by S. P. Colowick and N. O. Kaplan, Academic Press Inc. Publishers, 1957, p. 463 . 
ml) was brought to $80 \%$ saturation by the further addition of ammonium sulfate $(146 \mathrm{~g})$.

The precipitate was dissolved in water and dialyzed against distilled water over-night ("dialyzed ammonium sulfate fraction" 280 $\mathrm{ml}$ ).

Purification with a DEAE-cellulose column chromatography was carried out on a small scale.

The dialyzed ammonium sulfate fraction $(20 \mathrm{ml})$ was subjected to a chromatography on a DEAE-cellulose column $(3 \times 24 \mathrm{~cm})$ which had been equilibrated with $0.2 \mathrm{M}$ Tris- $\mathrm{HCl}$, $\mathrm{pH} 7.0$.

The column was eluted with $0.2 \mathrm{M}$ Tris$\mathrm{HCl}$, pH 7.0 containing increased concentration of $\mathrm{KCl}$ by 0 and $0.1 \mathrm{M}$, stepwise, and the enzyme was eluted by $0.2 \mathrm{M}$ Tris- $\mathrm{HCl}$, $\mathrm{pH} 0.7$ containing 0.1 м $\mathrm{KCl}$ ("DEAE fraction" $75 \mathrm{ml}$ ).

TABLE I. PURIFICATION OF NADP SPECIFIC POLYOL DEHYDROGENASE

\begin{tabular}{lcccc}
\multicolumn{1}{c}{ Fraction } & $\begin{array}{c}\text { Total } \\
\text { protein (mg) }\end{array}$ & $\begin{array}{c}\text { Total } \\
\text { units }\end{array}$ & $\begin{array}{c}\text { Specific** } \\
\text { activity }\end{array}$ & $\begin{array}{c}\text { Yield } \\
(0)\end{array}$ \\
$\begin{array}{l}\text { Crude extract } \\
\text { Dialyzed }\end{array}$ & 4196 & 84,630 & 20.2 & 100 \\
Am $_{2} \mathrm{SO}_{4}$ fraction & & & & \\
$(0.3 \sim 0.8$ Sat.) & 1865 & 70,870 & 38.0 & 83.7 \\
DEAE-fraction* & 194 & 57,530 & 296.1 & 68.0
\end{tabular}

* Corrected to represent the total quantity obtained from $430 \mathrm{ml}$ of crude extract.

** Specific activity units/mg protein.

The results of purification experiment are summarized in Table I. The purity of the enzyme is increased to about 15 -fold as compared with that of crude extract.

Properties of NADP specific polyol dehydrogenase

1) Substrate specificity. The enzyme has relative low specificity as shown in Table II. As can be seen in the Table, the OH-configuration at $\mathrm{C} 2$ - and $\mathrm{C} 4$ - of these sugars would participate on the action of reduction, and also the $\mathrm{OH}$-group of primary alcoholic hydroxyl-group must not be substituted by such a group as phosphate or carboxyl.
TABLE 11. EFFECT OF SUbSTRATES

$\begin{array}{lcc}\text { Substrate (1/15 M) } & \text { Units } & \begin{array}{c}\text { Relative Activity } \\ (\%)\end{array} \\ \text { D-Xylose } & 10.2 & 100 \\ \text { D-Ribose } & 7.0 & 69 \\ \text { L-Arabinose } & 22.0 & 216 \\ \text { D-Arabinose } & 0 & 0 \\ \text { D-Lyxose } & 0 & 0 \\ \text { D-Glucose } & 2.8 & 27 \\ \text { D-Galactose } & 8.3 & 81 \\ \text { D-Mannose } & 0 & 0 \\ \text { D-Fructose } & 0 & 0 \\ \text { R-5-P } & 0 & 0 \\ \text { G-6-P } & 0 & 0 \\ \text { D, L-Glyceraldehyde } & 20.4 & 200 \\ \text { Glucuronic acid } & 0 & 0 \\ \text { Galacturonic acid } & 0 & 0\end{array}$

2) Effects of aldoses and $\mathrm{NADPH}_{2}$ concentration on the reaction rate. At first, the effects of aldoses concentration on the reaction rate were tested with $\mathrm{D}$-xylose, D-ribose and L-arabinose, respectively.

Michaelis-Menten constants were calculated by the method of Lineweaver-Burk, $K m=$ $7.7 \times 10^{-3} \mathrm{M}$ for $\mathrm{D}$-xylose, $3.5 \times 10^{-3} \mathrm{M}$ for $\mathrm{L}-$ arabinose and $5.3 \times 10^{-2} \mathrm{M}$ for $\mathrm{D}$-ribose, respectively.

Next, effect of $\mathrm{NADPH}_{2}$ concentration of the reaction rate was also tested, $K m=$ $7.1 \times 10^{-5} \mathrm{M}$.

3) Coupling reaction of NADP specific polyol dehydrogenase with G-6-P : NADP oxidoreductase or threo-Ds-isocitrate : NADP oxidoreductase. Supply of $\mathrm{NADPH}_{2}$ from any other oxidation system is necessary for the completion of NADP specific polyol dehydrogenase reaction. The couple reaction between G-6-P, or threo-Ds-isocitrate: NADP oxidoreductase and NADP specific polyol dehydrogenase was examined. The results are shown in Fig. 1. Fig. 1 shows the reduction of NADP by G-6-P, or threo-Ds-isocitrate: NADP oxidoreductase and also the reoxidation of $\mathrm{NADPH}_{2}$ by $D$-xylose in the presence of the dialyzed ammonium sulfate fraction described in the purification procedure of this text as the NADP specific polyol dehydrogenase. 


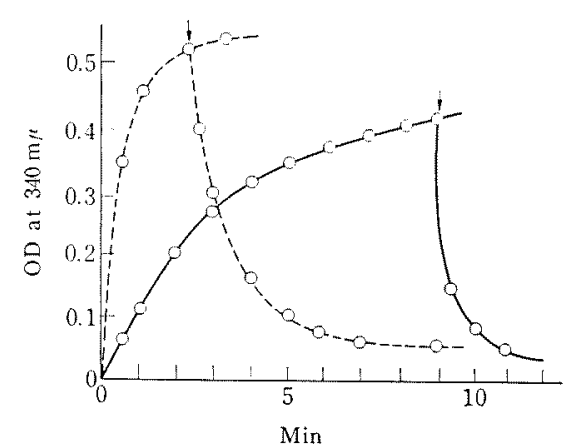

FIG. 1. Coupling Reaction of NADP Specific Polyol Dehydrogenase with G-6-P or threo-Ds-isocitrate: NADP Oxidoreductase.

Reaction mixture contained $2.0 \mathrm{ml}$ of $0.1 \mathrm{M}$ phosphate buffer, pH $7.0,0.2 \mathrm{ml}$ of $1.3 \times 10^{-3} \mathrm{M}$ $\mathrm{NADPH}_{2}, 0.2 \mathrm{ml}$ of $1 \mathrm{M}$ G-6-P or threo-Ds-isocitrate and $0.2 \mathrm{ml}$ of the "Dialyzed $\mathrm{Am}_{2} \mathrm{SO}_{4}$ fraction."

At the times indicated by the arrows, $0.2 \mathrm{ml}$ of $1 \mathrm{M} \mathrm{D}-\mathrm{xy}$ lose was added.

Symbols:

- O-, started by threo-Ds-isocitrate as substrate;

-.- - ---, started by G-6-P as substrate.

4) 0thers. As described in the previous paper, it has been found that some divalent cations are necessary for xylose-ketol isomerase activity involved in xylose-xylulose pathway, so it was examined whether such divalent metal ions have effect on NADP specific polyol dehydrogenase activity involved on xylose-xylitol-xylulose pathway, or not. As the result, it is revealed that $\mathrm{Mn}^{2+}, \mathrm{Mg}^{2+}$ and $\mathrm{Co}^{2+}$ which all had the stimulative effect on xylose-ketol isomerase activity did not show activation effect.

Next, effect of several inhibitors on NADP specific polyol dehydrogenase was examined. It was found that $p$-CMB, EDTA, NaF and $\mathrm{ICH}_{2} \mathrm{COOH}$ which all give effect on xyloseketol isomerase activity did not exhibit inhibitory effect at a final concentration of $10^{-3}$ м.

\section{Reaction product}

1) From D-xylose. The product obtained from $\mathrm{D}-\mathrm{xylose}$ by the above procedure was

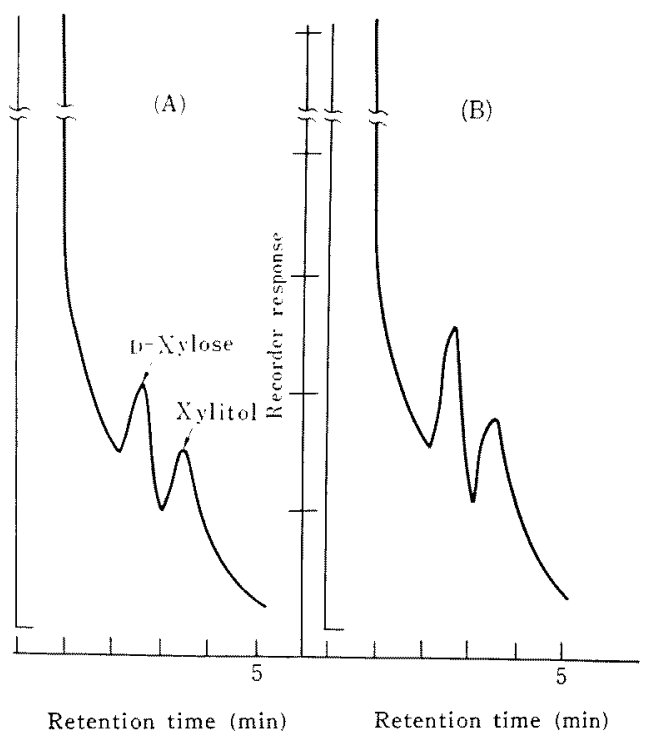

FIG. 2. Gas Chromatograms of Reaction Product with D-Xylose Used as Substrate.

(A) Mixture of authentic: (B) Reaction mixture D-xylose and xylitol

Conditions: Column $3 \mathrm{~mm} \times 150 \mathrm{~cm}$ stainless steel, Packing methylsilicone; Temp. $100^{\circ} \mathrm{C}$, He flow rate, $25 \mathrm{ml} / \mathrm{min}$.

characterized by gas chromatography.

The reaction mixture was heated in boiling water for $1 \mathrm{~min}$, and centrifuged to remove the enzyme protein. The supernatant solution was deionized with Amberlite IR 120 and Amberlite IR 45 in turn. The deionized solution was concentrated in vacuo to syrup. To the syrup was added methanol and the methanol soluble fraction was evaporated again to syrup. To the syrup was added pyridine and the pyridine solution obtained was treated with triethyl-chlorosilane to make triethylsilyl derivatives of the reaction products by the method of Sweeley et al. ${ }^{71}$

Next, the triethylsilyl derivatives of the reaction products obtained was analyzed using the standard Yanagimoto gas chromatographic

7) C.C. Sweeley, R. Bentley, M. Makita and W. W. Wells, J. Am. Chem. Soc., 85. 2497 (1963). 
equipment GCG-5DH type equipped with thermal conductivity detector.

Experimental conditions are shown in each figure. The result is shown in Fig. 2. Figure shows that, xylitol is the reaction product from $D$-xylose.

2) From L-arabinose. The same procedure was carried out for the reaction mixture of $\mathrm{L}$-arabinose. The result is shown in Fig. 3. Figure indicates that L-arabitol is the reaction product from L-arabinose.

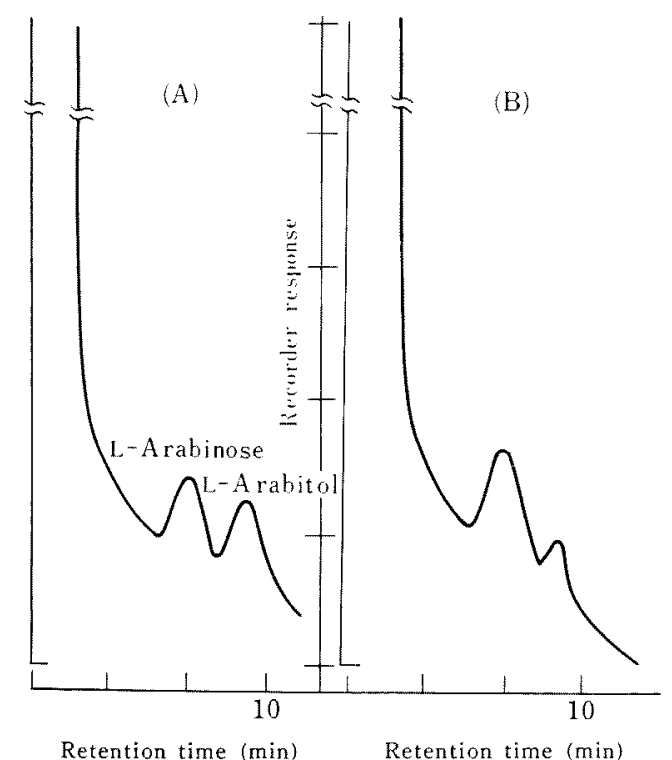

FIG. 3. Gas Chromatograms of Reaction Product with L-Arabinose Used as Substrate.

(A) Mixture of authentic: (B) Reaction mixture $\mathrm{L}$-arabinose and L-arabitol

Conditions: Same as Fig. 2 except that temperature being carried out at $80^{\circ} \mathrm{C}$.

\section{DISCUSSION}

As described above, it is clarified that xylose is converted to xylulose by two different pathways by Candida utilis; one through direct isomerization catalyzed by xylose-ketol isomerase and the other through reduction of xylose to xylitol by NADP specific polyol dehydrogenase, followed by oxidation of $x y-$ litol to xylulose by NAD specific dehydrogenase.

Further experiments are carried out on some properties of the NADP specific polyol dehydrogenase and the following results are clarified; NADP specific polyol dehydrogenase is extracted from Candida utilis by autolysis with butyl acetate instead of sodium bicarbonate extraction method reported by B. M. Scher and B. L. Horecker. ${ }^{5}$

The enzyme has a wide substrate specificity, that is, D-xylose, L-arabinose, D-ribose, Dglucose and D-galactose are to serve as the substrate. $\mathrm{NADPH}_{2}$ which is necessary for the enzyme action is supplied by the coupling reaction of G-6-P : NADP oxidoreductase and also threo-Ds-isocitrate: NADP oxidoreductase involved in T.C.A. cycle which has been already recognized in Candida utilis. ${ }^{81}$

The reaction products from $\mathrm{D}$-xylose and L-arabinose are respectively identified as $\mathrm{xy}$ litol and L-arabitol by gas chromatography.

Acknowledgement. The authors are grateful to Mr. T. Hosokawa for his assistance in these experiments and also to Dr. M. Miwa and Mr. T. Kihara, Toyo Spinning Co., for their kind helps.

8) M. Tomoeda and H. Horitsu, Res. Bull. Fac. Agr. Gifu Univ., 12, 175 (1960). 